\section{Rapid and Sustained Response to Tocilizumab in Patients with Polymyalgia Rheumatica Resistant or Intolerant to Glucocorticoids: A Multicenter Open-label Study}

\section{To the Editor:}

Polymyalgia rheumatica (PMR) is an inflammatory rheumatic disease affecting people aged 50 years or older. PMR usually improves with glucocorticoids (GC), with rapid resolution of symptoms in response to 15-20 $\mathrm{mg} / \mathrm{day}$ prednisone ${ }^{1}$. However, around half of the patients with PMR experience a flare of disease when GC are tapered or stopped, and these patients may require longterm GC treatment because of repeated relapses, leading to undesirable side effects. In addition, some patients with PMR have a partial response or do not respond to initial GC treatment ${ }^{1}$. In this setting, alternative treatments, namely GC-sparing agents, are required. Methotrexate gave conflicting results in PMR while tumor necrosis factor- $\alpha$ inhibitors failed to prevent relapses in randomized controlled studies.

Data suggest that interleukin 6 (IL-6) contributes to the inflammatory process of PMR ${ }^{2}$ : Increased serum levels of IL- 6 have been described in PMR and correlate with disease activity ${ }^{3}$; the risk of recurrence/relapse of PMR is associated with persistent elevated IL-6 serum levels as well as with a genetic polymorphism of the $I L-6$ promoter gene ${ }^{3}$; and reports described the efficacy of tocilizumab (TCZ), an anti-IL-6 receptor agent, in the treatment of giant cell arteritis $(\mathrm{GCA})^{4,5}$. The clinical value of TCZ in isolated PMR is less well described. This prompted us to analyze the potential use of this biological agent in patients with isolated PMR who are refractory or intolerant to GC.

A call to observe all cases of patients with PMR who received at least 1 infusion of TCZ was sent to the members of the French specialist network Club Rhumatismes et Inflammation (including rheumatologists and specialists in internal medicine). Patients had to satisfy the Healey criteria for $\mathrm{PMR}^{6}$ and have pure or predominant PMR clinical features.

During a 24-month period (2013-2014), 7 cases were declared (Table 1). Included patients ( 4 men) had a mean age of $73.4 \pm$ SD 7.9 and a mean duration of disease at time of TCZ initiation of $2.3 \pm 1.6$ years. They all had negative rheumatoid factor and anticyclic citrullinated peptide antibodies. The mean duration of GC treatment was $16.1 \pm 9.2$ months (range 1-48). Clinical features were pure PMR for 6 patients while 1 patient had PMR with biopsy-proven GCA, but without any related symptoms. Five patients had GC-refractory disease requiring a daily prednisone dosage of $20.7 \pm 4.5$ $\mathrm{mg}$. Two patients had concomitant metabolic diseases (diabetes and metabolic syndrome), and TCZ was thus started shortly after GC initiation
(1 and 2 months, respectively). Similarly, for 2 other patients, TCZ was introduced shortly after PMR diagnosis to avoid GC side effects. Immunosuppressive agents were given prior to TCZ in all patients, without significant improvement.

The patients received TCZ $8 \mathrm{mg} / \mathrm{kg}$ monotherapy monthly with a dramatic clinical improvement in all within 4 to 8 weeks. There was a simultaneous decrease in the PMR activity score and C-reactive protein levels (Figure 1). Four patients achieved low disease activity, 2 medium disease activity, and 1 patient still had high disease activity despite improvement. This was explained by persistent high visual analog scale and morning stiffness according to the patient. In parallel, GC dosage was tapered to 2.5 $\pm 2.2 \mathrm{mg}$. The mean number of TCZ infusions was $10.4 \pm 6.6$ (range 2-22). Patients were followed up for $19.4 \pm 7.1$ months: 4 stopped TCZ without relapse and 3 required treatment maintenance with TCZ. Finally, treatment was well tolerated without adverse events.

Seven similar cases of pure PMR treated by TCZ have previously been reported $^{7,8,9,10}$, while a substantially higher number of patients with GCA have received this biological agent ${ }^{4,5}$. In PMR cases, TCZ was given as a monthly $8 \mathrm{mg} / \mathrm{kg}$ infusion with a clinical response observed within 4 to 12 weeks. These patients had GC-resistant PMR with active disease despite immunosuppressive drugs, or they had safety concerns with GC. The clinical response was good except in 1 patient who failed to respond ${ }^{8}$. The followup period was generally 6 months without data on longterm outcome. Our series is in line with these results with a short time of response. In addition, the longterm followup indicates sustained response to TCZ in most of our patients. Mounting evidence suggests that IL-6 plays a major role in sustaining disease activity in PMR and its related disorder, GCA. Tocilizumab led to favorable results in GCA-specific symptoms and also in associated $\mathrm{PMR}^{4,5}$.

Taken together, these results strongly support the hypothesis that TCZ monotherapy is an active biological drug in the treatment of PMR and/or GCA as an adjunctive therapy for patients who have GC-refractory disease, and for those with GC side effects. Since GC remain a mainstay of therapy for these conditions, the appropriate time and context in which to introduce TCZ remain to be determined. In our series, TCZ was effective in patients who remained refractory after several months of GC, but also in the early phase of PMR. Remission was achieved in 3 cases after a limited number of TCZ infusions given shortly after GC initiation, and these patients had no relapse, suggesting that TCZ may be very effective when given early. Alternatively, when TCZ was given after a long duration of GC therapy, a clinical response was also obtained, but maintenance of the biological agent

Table 1. Clinical features, therapy, and outcomes of 7 patients with isolated PMR treated with TCZ. CRP levels and GC dosage were given before initiating TCZ and after the last TCZ infusion.

\begin{tabular}{|c|c|c|c|c|c|c|c|c|c|c|c|}
\hline $\begin{array}{l}\text { Patient } \\
\text { No. }\end{array}$ & $\begin{array}{c}\text { Age, } \\
\text { Yrs/Sex }\end{array}$ & $\begin{array}{c}\text { Duration of } \\
\text { GC Therapy } \\
\text { before Initiating } \\
\text { TCZ, Mos }\end{array}$ & $\begin{array}{l}\text { Previous } \\
\text { Drugs } \\
\text { before } \\
\text { TCZ }\end{array}$ & $\begin{array}{c}\text { PMR-AS } \\
\text { at the } \\
\text { Start of } \\
\text { TCZ }\end{array}$ & $\begin{array}{l}\text { PMR-AS } \\
\text { after TCZ, } \\
\text { Last } \\
\text { Assessment }\end{array}$ & $\begin{array}{l}\text { CRP at the } \\
\text { Start of } \\
\text { TCZ, mg/l }\end{array}$ & $\begin{array}{l}\text { CRP after } \\
\text { TCZ, mg/l, } \\
\text { Last } \\
\text { Assessment }\end{array}$ & $\begin{array}{l}\text { GC Dosage } \\
\text { at the Start } \\
\text { of TCZ, mg }\end{array}$ & $\begin{array}{c}\text { GC Dosage } \\
\text { after TCZ } \\
\text { Infusions, } \\
\mathrm{mg} / \mathrm{l}\end{array}$ & $\begin{array}{l}\text { No. TCZ } \\
\text { Infusions }\end{array}$ & $\begin{array}{l}\text { Followup } \\
\text { Duration, } \\
\text { Mos }\end{array}$ \\
\hline 1 & $65 / M$ & 20 & MTX & 41 & 23 & 30 & 5 & 15 & 0 & 19 & $20 \mathrm{TCZ}$ ongoing \\
\hline 2 & $78 / \mathrm{F}$ & 36 & IFX, ADA & 25 & 12 & 25 & 1 & 20 & 6 & 22 & $22 \mathrm{TCZ}$ ongoing \\
\hline 3 & $80 / \mathrm{M}$ & 1 & MTX & 37 & 1.5 & 100 & 5 & 25 & 0 & 2 & $20 \mathrm{TCZ}$ stopped \\
\hline 6 & $84 / \mathrm{F}$ & 3 & MTX & 26 & 2 & 40 & 5 & 25 & 5 & 2 & $25 \mathrm{TCZ}$ stopped \\
\hline 7 & $62 / \mathrm{M}$ & 48 & $\begin{array}{c}\text { MTX, ETA, } \\
\text { ADA }\end{array}$ & 24 & 2 & 2.9 & 2 & 15 & 4 & 4 & $4 \mathrm{TCZ}$ ongoing \\
\hline $\begin{array}{l}\text { Mean } \\
\pm \text { SD }\end{array}$ & $73.4 \pm 7.9$ & $16.1 \pm 9.2$ & & $32.3 \pm 7.8$ & $7.0 \pm 4.1$ & $56.9 \pm 24.1$ & $4.2 \pm 2.1$ & $20.7 \pm 4.5$ & $2.5 \pm 2.2$ & $10.4 \pm 6.6$ & $19.4 \pm 7.1$ \\
\hline
\end{tabular}

PMR: polymyalgia rheumatica; TCZ: tocilizumab; CRP: C-reactive protein; GC: glucocorticoids; PMR-AS: PMR activity score; M: male; F female; MTX: methotrexate; IFX: infliximab; ADA: adalimumab; LFM: leflunomide; ETA: etanercept. 
Early Initiation, $\mathrm{n}=4$

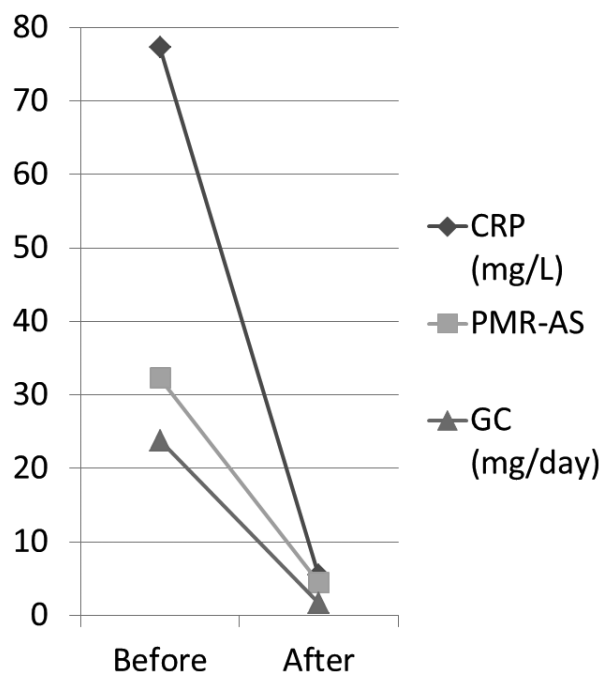

Late Initiation, $\mathbf{n}=\mathbf{3}$

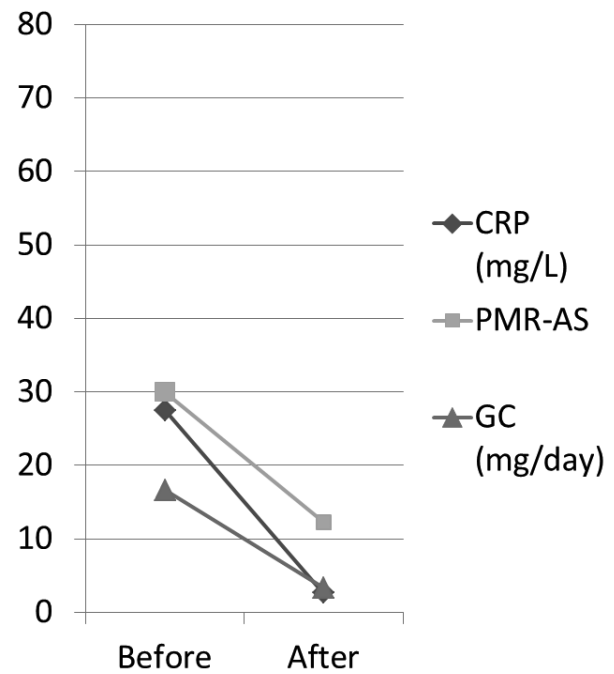

Figure 1. Changes in PMR-AS, CRP levels, and GC dosage (prednisone) following TCZ therapy in 7 patients with PMR. Since our series included patients with long duration of GC therapy (patients 1,2, and 7) and patients with short GC treatment (patients 3, 4,5, and 6), results are given separately for these 2 groups. The panel on the left shows patients for whom TCZ was introduced early after diagnosis (early initiation) and the panel on the right shows those with a late introduction of TCZ (late initiation). Assessments were performed just before the first infusion of TCZ and after the last TCZ infusion. PMR: polymyalgia rheumatica; PMR-AS: PMR activity score; CRP: C-reactive protein; GC: glucocorticoids; TCZ: tocilizumab.

was necessary. Thus, future studies must clarify the indications, when to introduce it, the predictive factors for good response, and the duration of TCZ therapy in the management of PMR.

ÉRIC TOUSSIROT, MD, PhD, Professor, Clinical Investigation Center in Biotherapy, Institut national de la santé et de la recherche médicale, Centre Investigation Clinique-1431, Fédération Hospitalo-Universitaire INCREASE, University Hospital of Besançon, and Department of Rheumatology, University Hospital of Besançon, and Department of Therapeutics and EA 4266 "Pathogens and Inflammation", Structure Fédérative de Recherche 4234, University of Franche-Comté, Besançon, France; ANTOINE MARTIN, MD, Department of Rheumatology, Hospital of Saint-Brieuc, Saint-Brieuc, France; MARTIN SOUBRIER, MD, PhD, Professor, Department of Rheumatology, University Hospital of Clermont-Ferrand, Clermont-Ferrand, France; SERGE REDEKER, MD, Department of Internal Medicine, Hospital of Abbeville, Abbeville, France; ALEXIS RÉGENT, MD, Department of Internal Medicine, University Hospital of Cochin, Paris, France. Address correspondence to Dr. Eric Toussirot, University Hospital, Clinical Investigation Center-Biotherapy, CHU Hopital St Jacques, Bat St Joseph, Besançon, 25000, France.E-mail: etoussirot@chu-besancon.fr

\section{ACKNOWLEDGMENT}

The authors are indebted to the Club Rhumatismes et Inflammation (Le CRI) for its help in conducting the study.

\section{REFERENCES}

1. Salvarani C, Cantini F, Hunder GG. Polymyalgia rheumatica and giant-cell arteritis. Lancet 2008;372:234-45.

2. Martinez-Taboada VM, Alvarez L, RuizSoto M, Marin-Vidalled MJ, Lopez-Hoyos M. Giant cell arteritis and polymyalgia rheumatica: role of cytokines in the pathogenesis and implications for treatment. Cytokine 2008;44:207-20.

3. Alvarez-Rodríguez L, Lopez-Hoyos M, Mata C, Marin MJ, Calvo-Alen J, Blanco R, et al. Circulating cytokines in active polymyalgia rheumatica. Ann Rheum Dis 2010;69:263-9.

4. Unizony S, Arias-Urdaneta L, Miloslavsky E, Arvikar S, Khosroshahi A, Keroack B, et al. Tocilizumab for the treatment of large-vessel vasculitis (giant cell arteritis, Takayasu arteritis) and polymyalgia rheumatica. Arthritis Care Res 2012;64:1720-9.

5. Loricera J, Blanco R, Hernández JL, Castañeda S, Mera A, Pérez-Pampín E, et al. Tocilizumab in giant cell arteritis: Multicenter open-label study of 22 patients. Semin Arthritis Rheum 2015;44:717-23.

6. Healey LA. Long-term follow-up of polymyalgia rheumatica: evidence for synovitis. Semin Arthritis Rheum 1984;13:322-8.

7. Mori S, Koga Y. Glucocorticoid-resistant polymyalgia rheumatica: pretreatment characteristics and tocilizumab therapy. Clin Rheumatol 2014 May 8 (E-pub ahead of print).

8. Macchioni P, Boiardi L, Catanoso M, Pulsatelli L, Pipitone N, Meliconi R, et al. Tocilizumab for polymyalgia rheumatica: report of two cases and review of the literature. Semin Arthritis Rheum 2013;43:113-8.

9. Hagihara K, Kawase I, Tanaka T, Kishimoto T. Tocilizumab ameliorates clinical symptoms in polymyalgia rheumatica. J Rheumatol 2010;37:1075-6.

10. Al Rashidi A, Hegazi MO, Mohammad SA, Varghese A. Effective control of polymyalgia rheumatica with tocilizumab. J Clin Rheumatol 2013;19:400-1.

J Rheumatol 2016;43:1; doi:10.3899/jrheum.150599 